\title{
Insect richness in dung patches of cattle raised in two livestock systems
}

\section{Marcos Rafael Gusmão ${ }^{1}$, Marcia Cristina de Sena Oliveira ${ }^{1}$, Maria Luiza Franceschi Nicodemo $^{1}$, Jose Ricardo Macedo Pezzopane ${ }^{1}$}

\author{
${ }^{1}$ Embrapa Pecuária Sudeste, São Carlos, São Paulo, Brasil. E-mail: marcos.gusmao@embrapa.br, marcia.sena-oliveira@embrapa.br, \\ marialuiza.nicodemo@embrapa.br, jose.pezzopane@embrapa.br
}

Received: 24/10/2019; Accepted: 05/02/2020.

\section{ABSTRACT}

The negative impact of livestock breeding on the environment has been mitigated through the combination of pastures and trees, characterizing the silvopastoral systems (SPS), an alternative to conventional pasture systems (CPS). The SPS provides environmental services, particularly the recovery of degraded areas and carbon sequestration. Furthermore, the complexity of the SPS can improve other environmental services, for example, enhance biodiversity and reduce pests through biological control. However, it is not clear the relationship between microclimate, pasture, trees, cattle, and invertebrate present in this environment. The purpose of this research was to characterize the macrofauna and determine the richness and abundance of invertebrates associated with dung patches of cattle raised in SPS and CPS pasture systems during two years in Brazil. As a result, we verified that the presence of trees in pastures alters the environment, notably through the reduction of solar radiation; decreases the wind speeds; attenuates the air and soil temperature, and diversifies the food supply, with the promotion of beneficial insect richness in dung patches of cattle. The diversity index of invertebrate fauna associated with dung patches in the SPS and CPS were respectively, 1.9 and 1.3. Besides that, the SPS contributed to higher densities of pupal parasitoids insects represented by Aphaereta sp. and Spalangia sp., the most important cattle ectoparasite controllers. In this way, we concluded that the integrated pasture systems are an essential tool for biodiversity improvement, especially the beneficial insects living in dung patches, which can contribute to reducing cattle ectoparasite infestations.

Keywords: Insect diversity, Predators, Parasitoids, Cattle ectoparasites.

\section{Riqueza de insetos associados em bolos fecais de bovinos criados em dois sistemas de produção pecuária}

\section{RESUMO}

O impacto negativo da criação de bovinos ao meio ambiente tem sido mitigado pela combinação de pastagens e árvores, caracterizando os sistemas silvipastoris (SPS), uma alternativa aos sistemas convencionais de pastagem (CPS). O SPS fornece serviços ambientais, particularmente a recuperação de áreas degradadas e o seqüestro de carbono. Além disso, a complexidade do SPS pode melhorar outros serviços ambientais, por exemplo, aumentar a biodiversidade e reduzir pragas através do controle biológico. No entanto, não está clara a relação entre microclima, pastagem, árvores, bovinos e invertebrados presentes neste ambiente. O objetivo desta pesquisa foi caracterizar a macrofauna e determinar a riqueza e abundância de invertebrados associados a fezes de bovinos criados em sistemas de pastagem SPS e CPS durante dois anos no Brasil. Como resultado, verificamos que a presença de árvores em pastagens altera o meio ambiente, principalmente através da redução da radiação solar; diminui a velocidade do vento; atenua a temperatura do ar e do solo e diversifica o suprimento de alimentos, com a promoção da riqueza de insetos benéficos associados aos bolos fecais de bovinos. O índice de diversidade da fauna de invertebrados associado aos bolos fecais de bovinos no SPS e no CPS foi, respectivamente, 1,9 e 1,3. Além disso, o SPS contribuiu para maiores densidades de insetos parasitóides de pupas de dípteros, representados por Aphaereta sp. e Spalangia sp., os mais importantes controladores de ectoparasitas em bovinos. Dessa forma, concluímos que os sistemas integrados de pastagens são uma ferramenta importante para a melhoria da biodiversidade, principalmente os insetos benéficos que vivem associados às fezes bovinas, o que pode contribuir para a redução das infestações por ectoparasitas em bovinos.

Palavras-chave: Diversidade de insetos, Predadores, Parasitóides, Ectoparasitas de bovinos. 


\section{Introduction}

The silvopastoral systems (SPS) are important socioeconomic components of the economies of countries of Tropical America. When implanted and well managed, they become key land-use systems for the provision of environmental services, particularly the recovery of degraded areas and carbon sequestration. Also, they can provide viable economic alternatives to farmers (Amézquita et al., 2004). The SPS combines trees with pasture and needs more labor and financial resource per hectare than existing technologies (Conventional Pasture Systems - CPS); consequently, they have the potential of reducing the conversion of forest to pasture (Kaimowitz and Angelsen, 2008).

The combination of pastures and trees can contribute to mitigating the negative impact of livestock breeding on the environment. The adoption of SPS can favor adequate microclimate environmental conditions for cattle (Pezzopane et al., 2015), improve soil fertility and groundwater recharge, reduce erosion, improve water quality, sequester carbon, enhance biodiversity (Cardona et al., 2014; Auad et al., 2012; Vallejo et al., 2012; Jose, 2009), and consequently reduce pests and diseases (Gorgen et al., 2008; Inomoto et al., 2007; Burgess, 1999).

Tropical climates favor the development of various ectoparasites that afflict cattle, especially the horn fly Haematobia irritans, the botfly Dermatobia hominis and the cattle tick Rhipicephalus microplus (Grisi et al., 2014). However, on the same climatic conditions, a diversity of invertebrate organisms living on ground soil and in dung patches can contribute to biological control of ectoparasites, maintaining its populations below the economic threshold (Mendes and Linhares, 2002).

The environmental services, as biological control, delivered from SPS, are described in the literature (Navas et al., 2008). However, the relationship between microclimate, pasture, trees, cattle, and invertebrate present in this environment is still not clear. The objectives of this study were the characterization of macrofauna and the determination of richness of invertebrates associated with dung patches of cattle raised in SPS and CPS systems.

\section{Material and Methods}

\subsection{Characterization of the systems}

The studied area was located at São Carlos, SP, Brazil $\left(22^{\circ} 01^{\prime} 10^{\prime \prime}\right.$ South latitude, 47 53'38" West longitude). The climate classification of the local is Cwa-Awa (Köppen), with a dry season from April to September and a rainy season from October to March. The average yearly temperature is $21.2{ }^{\circ} \mathrm{C}$, and the average annual relative humidity is $75.6 \%$. The terrain has slopes of $3 \%$ to $5 \%$ and an average altitude of $860 \mathrm{~m}$.
The silvopastoral system was established in December 2007, in an area formed by Urochloa decumbens (syn. Brachiaria decumbens) on Oxisol (Soil Survey Staff, 2014). Two areas measuring $275 \mathrm{~m} \mathrm{x} 140 \mathrm{~m}$ were divided into six paddocks (0.41 ha). The forest species were planted directly in the pasture (Anadenanthera colubrina, Peltophorum dubium, Zeyheria tuberculosa, Cariniana estrellensis, Piptadenia gonoacantha, Guazuma ulmifolia, and Croton floribundus), in three rows, accompanying the terrain, at a spacing of $2.5 \mathrm{~m} \mathrm{x}$ $2.5 \mathrm{~m}$, resulting around 600 trees/ha. Each row of trees occupies seven meters and is separated from the pasture with an electric fence at one meter. Pasture occupies 15 $\mathrm{m}$ between the rows.

The herd consisted of 32 male Canchim cattle (16 in each system SPS and CPS), weaned at eight months of age. The cattle were submitted to rotational grazing, according to Euclides and Euclides Filho (1998). At the end of each grazing cycle (42 days), the animals were taken to a corral for the ectoparasites counting. All the animals were treated with the same acaricide on seven occasions (August, October, and December 2013; May, July, November, and December 2014), when the number of adult female ticks was higher than 50. An acaricide with the shortest possible residual period (ten days), was used and all animals received treatment at the same time, regardless of the pasture system. All procedures for parasite count in the animals' bodies were made according to animal welfare principles and were approved by the Embrapa Ethics Committee (CEUA-CPPSE / PRT 04/2013).

\subsection{Meteorological parameters}

The water balance, according to Thornthwaite and Mather (1955), was calculated based on temperature and rainfall recording at the Embrapa Southeast Livestock climatological station. The microclimate in each system was characterized by the data on air and soil temperature, global solar radiation $\left(\mathrm{MJ} \mathrm{m}^{-2} \mathrm{day}^{-1}\right)$, and wind incidence $\left(\mathrm{m} \mathrm{s}^{-1}\right)$. The data were measured continually at four points between the two rows of trees in the SPS and one point in the CPS and were used to calculate the monthly means. Weekly the soil moisture was measured with a collection module and capacitance sensor $\left(\right.$ Diviner $\left.^{\circledR}\right)$. In the CPS, data were obtained at four pasture points at random, while in the SPS, the access tubes to measure moisture were installed at four locations between the two rows of trees. The values were the means of the four measurements in both systems.

\subsection{Grass height}

A tape measure was used to determine the grass height in two paddocks in each season, in an area delineated by squares $(0.50 \times 0.50 \mathrm{~m})$, with five 
repetitions per paddock and three measurements in each square. In the silvopastoral system, the aboveground part of the grass was measured at three distances from the trees $(2.0 \mathrm{~m}, 4.75 \mathrm{~m}$, and $8.5 \mathrm{~m})$, on one side of the rows of trees, with five replications for each distance. In the conventional system, the measurements were made randomly in the paddocks.

\subsection{Invertebrate macrofauna associated with the dung patches}

At the end of the seventh day of grazing, 15 recently dropped dung patches were selected randomly and left exposed to the environmental conditions for 14 days to evaluate the invertebrate macrofauna. Then they were collected along with the underlying soil to a depth of 5 $\mathrm{cm}$ and placed in white plastic trays $(7.7 \times 36.0 \times 44.0$ $\mathrm{cm}$ ) and taken to the laboratory for incubation for 40 days in a Berlese funnel to obtain the adults. This evaluation was performed three times, in the spring of 2014 and summer and winter of 2015. After the incubation period, the predator morph-species were obtained and quantified. The morph-species (S) were identified to the order and family taxon.

At the end of the occupation period of each paddock, ten dung patches were selected in four paddocks of each system (SPS and CPS) to evaluate the Diptera and their parasitoids. After exposure for seven days, the dung patches were collected with the underlying soil layer to a depth of $5 \mathrm{~cm}$. The material was taken to the laboratory for the separation of the insect pupae by the flotation method (Tobin and Pitts, 1999). The pupae were placed individually in micro tubes with a volume of $1.5 \mathrm{ml}$ and were kept in a BOD incubator $\left(25 \pm 5{ }^{\circ} \mathrm{C}\right.$, $65 \% \mathrm{RH})$ until the emergence of the flies or pupal parasitoids. These evaluations were carried out in the winter, spring, and summer of 2013, autumn, winter, spring, and summer of 2014 and the autumn and winter of 2015 .

\subsection{Statistical analysis of the data}

The climate data were analyzed using the GLM routine (SAS, 2003). The grass height data were analyzed for normality (Kolmogorov and Shapiro-Wilks tests), followed by the analysis of variance by the Kruskal-Wallis test $(\mathrm{P}<0.05)$, using the Infostat software (Di Rienzo et al., 2011). The data of invertebrate macrofauna associated with the dung patches were analyzed from the number of individuals $\left(\mathrm{n}_{\mathrm{i}}\right)$ of each morph-species (S), and the invertebrate diversities related to the two pasture systems (SPS and CPS) were determined by applying the Shannon index $\left(\mathrm{H}^{\prime}\right)$, calculated in function of the relative abundance (proportion) $\left(\mathrm{p}_{\mathrm{i}}\right)$ of morph-species $(i)$ in the sample $(\mathrm{N})$, where $\mathrm{H}^{\prime}=-\sum_{\mathrm{i}=1}^{\mathrm{S}} \mathrm{p}_{\mathrm{i}} \times \mathrm{LNp}_{\mathrm{i}}$, with $\mathrm{p}_{\mathrm{i}}=\mathrm{n}_{\mathrm{i}} / \mathrm{N}$.
Through the diversity index $\mathrm{H}^{\prime}$, the equivalent number of morph-species $\left(\mathrm{S}_{\mathrm{H}^{\prime}}\right)$ for each system was determined, given by the equation $\mathrm{S}_{\mathrm{H}^{\prime}}=\mathrm{e}^{\mathrm{H} \prime}$ (Odum, 1983; Pielou, 1975). The densities of flies (pupae and adults) and fly parasitoids were submitted to analysis of variance (ANOVA) by the LSMEANS option of SAS (SAS, 2003), considering the effects of pasture system (SPS or CPS) and evaluation period (season of the year). The mean insect densities of the treatments with significant results according to the ANOVA were compared by the Duncan and Student-Newman-Keuls test $(\mathrm{P} \leq 0.05)$.

\section{Results and Discussion}

A water deficit from July to the beginning of September was registered in 2013. On the contrary, excess water in the soil caused by the rains, with the peak in October, was recorded in October, November, and December. In 2014 there was severe water deficit from January to October, followed by rainfall in November, causing the first water excesses for the year. In 2015, water excesses occurred in February and March, after, there was a decrease of rainfall until JuneJuly when there was a small water excess (Figure 1).

The solar radiation was lower in the SPS in all the evaluations $(\mathrm{P}<0.05)$, with the average value of $10.83 \pm 0.17 \mathrm{MJ} \mathrm{m}^{-2} \mathrm{day}^{-1}$ in the SPS, and $17.35 \pm 0.17 \mathrm{MJ}$ $\mathrm{m}^{-2}$ day $^{-1}$ in the CPS. In the SPS, the greatest attenuations of solar radiation were observed in April 2014 and March 2015, with values higher than 50\%, probably due to the solar declination and greater leaf growth of the trees in this period. Significant differences $(\mathrm{P}<0.05)$ were also observed for average wind speed in the two systems, with means of $1.36 \pm 0.02 \mathrm{~m} / \mathrm{s}$ for the CPS and $0.64 \pm 0.02 \mathrm{~m} / \mathrm{s}$ for the SPS, and reductions from $34.8 \%$ to $65.1 \%$ in the SPS concerning the CPS.

Average temperatures also differed significantly $(\mathrm{P}<0.05)$ between the systems, with values of $22.47 \pm 0.05^{\circ} \mathrm{C}$ (CPS) and $22.22 \pm 0.05^{\circ} \mathrm{C}$ (SPS) for soil temperatures; and $21.42 \pm 0.07{ }^{\circ} \mathrm{C}$ (CPS) and 21.19 \pm 0.07 ${ }^{\circ} \mathrm{C}$ (SPS) for air temperatures. The quantities of water stored in the topmost soil layer $(0-10 \mathrm{~cm})$ in the pastures of the two experimental areas did not differ significantly $(0.21 \pm 0.03 \mathrm{~mm})$. Though, the lowest average quantity of water $(0.20 \pm 0.04 \mathrm{~mm})$ was registered below the trees in the SPS.

The animals were set in the paddocks when the grass height was between 30 and $40 \mathrm{~cm}$, and they were withdrawn when the grass height was between 15 and $20 \mathrm{~cm}$. The grass height varied significantly $(\mathrm{P}<0.05)$ between the systems, both before and after grazing (Table 1). However, it was possible to maintain the grass height within the established limits in $70 \%$ of the evaluations. Due to the methodology employed, which consisted of a random sampling of the grass, it is 
feasible that during winter (when pasture growth is limited due to lower temperatures, shorter day lengths, and water scarcity), negative growth rates for the grass have been registered.

The grass pasture height before grazing in SPS was higher than the CPS, and the opposite was observed after grazing. Probably this had contributed to similar quantities of water stored in the topmost soil layer registered in the pastures on both systems, and consequently, the pasture component did not interfere with the richness of invertebrate macrofauna between the systems. The invertebrate richness values (number of morph-species) for the SPS and CPS in the seasonal periods were 38 and 31 morph-species in the spring, 33, and 23 morph-species in the summer, and 27 and 18 morph-species in the winter, respectively (Table 2). In the SPS system was registered higher total richness (98) than in the CPS system (72). However, the invertebrate abundance in the CPS $(24,810)$ was higher than in the SPS $(7,952)$ (Table 2).

The average number per season of the second morph-species of Diptera: Stratiomyidae $(6,515)$ with a relative abundance of 0.4964 contributed to higher invertebrate abundance in the CPS system (Table 3). This Stratiomyidae morph-species was the most abundant in SPS, too, with 0.3471. In general, the Stratiomyidae larvae are effective in reducing nutrients and modifying moisture contained in manure because of their feeding behavior through the organic matter decomposition (Ferrari et al., 2009). Differently, in the SPS system was registered 58.82 percent (thirty from fifty-one) of invertebrate morph-species with relative abundance higher than in the CPS system (Table 3). The main taxonomic groups comprised three morph-species of carnivore/detritivore Coleoptera: Staphylinidae (relative abundance of 0.1354 morph-species number 2 , 0.2831 morph-species number 3 and 0.0166 morphspecies number 4), and one morph-species of carnivore Hymenoptera (Solenopsis sp.) with a relative abundance of 0.0457 (Table 3).

The average diversity indices $\left(\mathrm{H}^{\prime}\right)$ for the SPS and CPS were 1.9 and 1.3 , respectively. The numbers of equivalent morph-species $\left(\mathrm{SH}^{\prime}\right)$ considering the diversity $\mathrm{H}^{\prime}$ of each system were six morph-species in the SPS and four morph-species in the CPS (Table 4). These values represent the number of morph-species that would be expected in each system if all morphspecies has the same abundance (maximum evenness).

In the raining seasons (spring and summer) and the autumn 2015 were registered the higher fly pupae and adult densities. However, pupae parasitoids densities had a higher occurrence in the autumn of 2014 and 2015 (Table 5).

Six Diptera morph-species were identified in the dung patches: three morph-species of Muscidae, with an identification of individuals of the species Haematobia irritans, two morph-species of Sarcophagidae and one morph-species of Fanniidae. Two morph-species of Hymenoptera parasitoids of the Braconidae and Pteromalidae were found parasitizing fly pupae, with the morph-species identified as Aphaereta sp. and Spalangia sp. The most significant occurrences of these natural enemies of flies were observed in the SPS. The average densities of pupae, adults, and pupal parasitoids in the SPS and CPS were respectively 28.7 and 35.1; 11.5 and 13; and 22.8 and 6.3 insects/10 dung patches (Table 6) (these data were partially published in Oliveira et al., 2017).

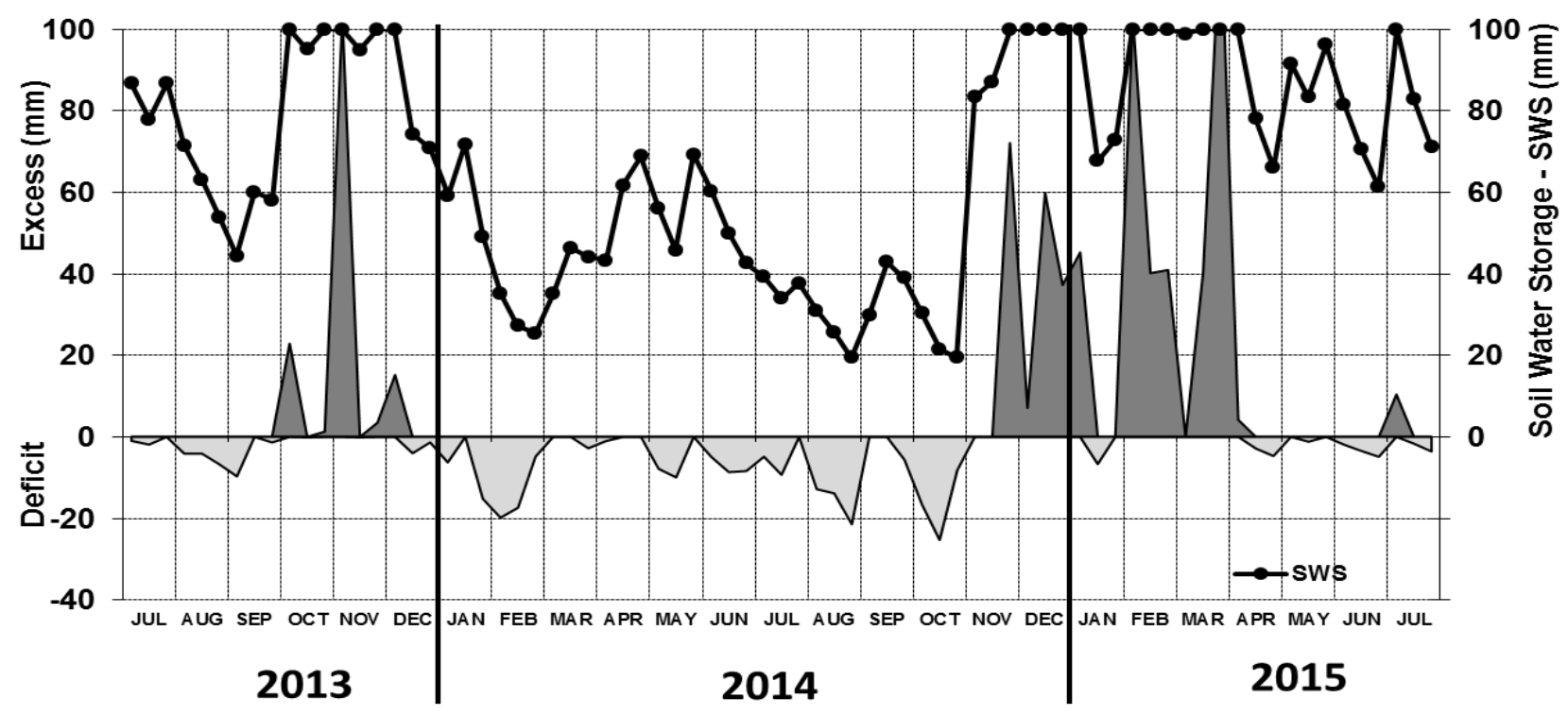

Figure 1. Water balance between July 2013 and July 2015, measured by the Embrapa Southeast Livestock climatological station, São Carlos, SP. 
Table 1. Grass height $(\mathrm{cm})$ before grazing and after grazing according to the type of system: silvopastoral system (SPS) or conventional pasture system (CPS).

\begin{tabular}{|c|c|c|c|c|}
\hline \multirow{3}{*}{ Season/year } & \multicolumn{4}{|c|}{ Type of System } \\
\hline & \multicolumn{2}{|c|}{ Before Grazing } & \multicolumn{2}{|c|}{ After Grazing } \\
\hline & CPS & SPS & CPS & SPS \\
\hline Winter 2013 & $10.8 \pm 1.6 \mathrm{a}^{*}$ & $19.9 \pm 5.0 \mathrm{~b}$ & $12.3 \pm 7.3 \mathrm{a}$ & $15.1 \pm 6.8 \mathrm{~b}$ \\
\hline Spring 2013 & $17.4 \pm 6.4 \mathrm{a}$ & $37.6 \pm 13.4 \mathrm{~b}$ & $11.2 \pm 5.7 \mathrm{a}$ & $21.4 \pm 8.2 \mathrm{~b}$ \\
\hline Summer 2013 & $34.8 \pm 14.7 \mathrm{a}$ & $40.0 \pm 9.8 \mathrm{~b}$ & $20.8 \pm 13.5 \mathrm{a}$ & $22.1 \pm 7.8 \mathrm{~b}$ \\
\hline Autumn 2014 & $28.8 \pm 8.9 \mathrm{a}$ & $31.7 \pm 12.3 \mathrm{a}$ & $29.4 \pm 10.1 \mathrm{a}$ & $26.6 \pm 10.1 \mathrm{a}$ \\
\hline Winter 2014 & $17.8 \pm 8.2 \mathrm{a}$ & $10.2 \pm 7.4 \mathrm{~b}$ & $23.0 \pm 13.1 \mathrm{a}$ & $14.0 \pm 8.1 \mathrm{~b}$ \\
\hline Spring 2014 & $23.2 \pm 13.8 \mathrm{a}$ & $31.6 \pm 12.5 b$ & $21.0 \pm 8.6 \mathrm{a}$ & $16.4 \pm 8.1 \mathrm{~b}$ \\
\hline Summer 2014 & $52.5 \pm 16.1 \mathrm{a}$ & $47.0 \pm 13.6 \mathrm{~b}$ & $26.9 \pm 17.6 \mathrm{a}$ & $16.9 \pm 9.3 b$ \\
\hline Autumn 2015 & $35.3 \pm 13.3 \mathrm{a}$ & $22.8 \pm 11.2 \mathrm{~b}$ & $35.7 \pm 17.7 \mathrm{a}$ & $20.0 \pm 12.1 \mathrm{~b}$ \\
\hline General average & $29.7 \pm 16.6 \mathrm{a}$ & $31.4 \pm 16.1 \mathrm{~b}$ & $23.5 \pm 14.8 \mathrm{a}$ & $19.3 \pm 9.9 b$ \\
\hline \multicolumn{5}{|c|}{$\begin{array}{l}\text { * Different letters between the systems in the same season/year indicate a significant difference between the means ( } \mathrm{P}<0.05 \text {, Kruskal } \\
\text { Wallis test). }\end{array}$} \\
\hline \multicolumn{5}{|c|}{$\begin{array}{l}\text { Table 2. Richness and abundance of invertebrate fauna associated with cattle dung patches in the silvopastoral system (SPS) a } \\
\text { conventional pasture system (CPS) in spring } 2014 \text { and summer and winter } 2015 \text {. }\end{array}$} \\
\hline System & Season/year & \multicolumn{2}{|c|}{ ichne } & Abundance \\
\hline \multirow{4}{*}{ SPS } & Spring 2014 & \multicolumn{2}{|c|}{38} & 1,899 \\
\hline & Summer 2015 & \multicolumn{2}{|c|}{33} & 3,528 \\
\hline & Winter 2015 & \multicolumn{2}{|c|}{27} & 2,525 \\
\hline & Total & \multicolumn{2}{|c|}{98} & 7,952 \\
\hline \multirow{4}{*}{ CPS } & Spring 2014 & \multicolumn{2}{|c|}{31} & 987 \\
\hline & Summer 2015 & \multicolumn{2}{|c|}{23} & 20,712 \\
\hline & Winter 2015 & \multicolumn{2}{|c|}{18} & 3,111 \\
\hline & Total & \multicolumn{2}{|c|}{72} & 24,810 \\
\hline
\end{tabular}

Table 3. Average number and relative abundance of invertebrate associated with cattle dung patches in the silvopastoral system (SPS) and conventional pasture system (CPS) during spring 2014 and summer and winter 2015.

\begin{tabular}{|c|c|c|c|c|}
\hline \multirow{2}{*}{ Class or Order } & \multirow{2}{*}{ Order or Family } & \multirow{2}{*}{ Morph-species } & \multicolumn{2}{|c|}{ Number (relative abundance) } \\
\hline & & & SPS & CPS \\
\hline Arachnida & Acari & 1 & $7.33(0.0039)$ & $0.00(0.00)$ \\
\hline Arachnida & Acari & 2 & $26.00(0.0105)$ & $4.33(0.0010)$ \\
\hline Arachnida & Araneae & 1 & $3.33(0.0015)$ & $1.00(0.0007)$ \\
\hline Blatodea & Blatidae & 1 & $0.00(0.00)$ & $0.33(0.0003)$ \\
\hline Chilopoda & Scolopendromorpha & 1 & $3.33(0.0015)$ & $1.33(0.0014)$ \\
\hline Chilopoda & Scolopendromorpha & 2 & $11.33(0.0043)$ & $1.00(0.0003)$ \\
\hline Clitellata & Haplotaxida & 1 & $3.33(0.0015)$ & $1.33(0.0001)$ \\
\hline Coleoptera & Anthicidae & 1 & $0.67(0.0003)$ & $0.00(0.00)$ \\
\hline Coleoptera & Anthicidae & 2 & $4.33(0.0019)$ & $1.67(0.0005)$ \\
\hline Coleoptera & Anthicidae & 3 & $0.33(0.0002)$ & $0.33(0.0003)$ \\
\hline Coleoptera & Anthicidae & 4 & $5.00(0.0017)$ & $6.67(0.0021)$ \\
\hline Coleoptera & Anthicidae & 5 & $0.67(0.0002)$ & $0.33(0.0003)$ \\
\hline Coleoptera & Carabidae & 1 & $0.33(0.0002)$ & $0.00(0.00)$ \\
\hline Coleoptera & Histeridae & 1 & $11.00(0.0042)$ & $19.00(0.0037)$ \\
\hline Coleoptera & Histeridae & 2 & $1.00(0.0004)$ & $0.00(0.00)$ \\
\hline Coleoptera & Histeridae & 3 & $15.67(0.0063)$ & $1.67(0.0010)$ \\
\hline Coleoptera & Histeridae & 4 & $1.00(0.0004)$ & $1.00(0.0004)$ \\
\hline Coleoptera & Histeridae & 5 & $23.67(0.0096)$ & $83.67(0.0339)$ \\
\hline Coleoptera & Scarabaeidae & 1 & $0.67(0.0003)$ & $1.67(0.0014)$ \\
\hline Coleoptera & Scarabaeidae & 2 & $6.67(0.0034)$ & $2.33(0.0019)$ \\
\hline Coleoptera & Scarabaeidae & 3 & $2.67(0.0009)$ & $11.00(0.0034)$ \\
\hline Coleoptera & Staphylinidae & 1 & $0.00(0.00)$ & $4.00(0.0041)$ \\
\hline Coleoptera & Staphylinidae & 2 & $339.67(0.1354)$ & $499.67(0.1077)$ \\
\hline Coleoptera & Staphylinidae & 3 & $747.00(0.2831)$ & $784.67(0.2094)$ \\
\hline Coleoptera & Staphylinidae & 4 & $41.33(0.0166)$ & $65.00(0.0121)$ \\
\hline Dermaptera & Labiduridae & 1 & $17.33(0.0087)$ & $2.33(0.0011)$ \\
\hline Diptera & Calliphoridae & 1 & $0.67(0.0002)$ & $15.67(0.0008)$ \\
\hline Diptera & Calliphoridae & 1 & $0.00(0.00)$ & $1.67(0.0017)$ \\
\hline
\end{tabular}




\begin{tabular}{ccccc} 
Diptera & Chironomidae & 1 & $36.00(0.0143)$ & $32.00(0.0142)$ \\
\hline Diptera & Chironomidae & 2 & $34.33(0.0137)$ & $0.33(0.0001)$ \\
\hline Diptera & Muscidae & 1 & $15.67(0.0048)$ & $8.33(0.0015)$ \\
\hline Diptera & Phoridae & 1 & $24.33(0.0089)$ & $77.67(0.0240)$ \\
\hline Diptera & Sarcophagidae & 1 & $1.00(0.0004)$ & $0.00(0.00)$ \\
\hline Diptera & Stratiomyidae & 1 & $8.33(0.0026)$ & $59.67(0.0347)$ \\
\hline Diptera & Stratiomyidae & 2 & $1,010.00(0.3471)$ & $6,515.00(0.4964)$ \\
\hline Diptera & Tipulidae & 1 & $0.00(0.00)$ & $3.33(0.0034)$ \\
\hline Hemiptera & Anthocoridae & 1 & $20.00(0.0078)$ & $11.00(0.0023)$ \\
\hline Hemiptera & Miridae & 1 & $4.67(0.0018)$ & $6.67(0.0026)$ \\
\hline Hymenoptera & Encyrtidae & 1 & $2.33(0.0012)$ & $4.00(0.0041)$ \\
\hline Hymenoptera & Formicidae & 1 & $17.67(0.0085)$ & $2.67(0.0024)$ \\
\hline Hymenoptera & Formicidae & 2 & $5.33(0.0023)$ & $15.00(0.0065)$ \\
\hline Hymenoptera & Formicidae & $34.33(0.0145)$ & $17.00(0.0137)$ \\
\hline Hymenoptera & Formicidae & $0.00(0.00)$ & $2.00(0.0020)$ \\
\hline Hymenoptera & Solenopsis & 4 & $105.00(0.0457)$ & $0.00(0.00)$ \\
\hline Isoptera & Termitidae & 1 & $24.33(0.0119)$ & $1.67(0.0017)$ \\
\hline Lepidoptera & - & 1 & $1.33(0.0005)$ & $1.00(0.00005)$ \\
\hline Malacostraca & Isopoda & 1 & $32.33(0.0167)$ & $0.00(0.00)$ \\
\hline Orthoptera & Acrididae & 1 & $0.00(0.00)$ & $0.67(0.0007)$ \\
\hline Orthoptera & Gryllidae & 1 & $0.33(0.0002)$ & $0.00(0.00)$ \\
\hline Orthoptera & Gryllidae & 1 & $0.00(0.00)$ & $0.33(0.0003)$ \\
\hline Scorpiones & Buthidae & 2 & $0.33(0.0001)$ & $0.00(0.00)$ \\
\hline
\end{tabular}

Table 4. Diversity of invertebrate fauna associated with cattle dung patches in the silvopastoral system (SPS) and conventional pasture system (CPS) in spring 2014 and summer and winter 2015.

\begin{tabular}{lcccc}
\hline \multirow{2}{*}{ Season/year } & \multicolumn{2}{c}{ Diversity $\left(\mathrm{H}^{\prime}\right)$} & \multicolumn{2}{c}{ Equivalent morph-species (SH') } \\
\cline { 2 - 5 } & SPS & CPS & SPS & CPS \\
\hline Spring 2014 & 2.3 & 2.1 & 9 & 2 \\
\hline Summer 2015 & 1.4 & 0.5 & 4 & 4 \\
\hline Winter 2015 & 2.0 & 1.4 & 7 & 4 \\
\hline Mean & 1.9 & 1.3 & 6 & \\
\hline
\end{tabular}

Table 5. Densities of Diptera pupae and adults, and pupal parasitoids in the function of seasons from 2013 to 2015.

\begin{tabular}{lccc}
\hline \multirow{2}{*}{ Season/year } & \multicolumn{2}{c}{ Diptera } & \multirow{2}{*}{ Parasitoids } \\
\cline { 2 - 3 } & Pupae & Adults & $5.0 \pm 2.5 \mathrm{~b}$ \\
Winter 2013 & $13.0 \pm 3.3 \mathrm{bcd}$ & $7.12 \pm 2.6 \mathrm{abc}$ & $1.9 \pm 1.3 \mathrm{~b}$ \\
Spring 2013 & $59.2 \pm 23.7 \mathrm{abc}$ & $8.2 \pm 4.1 \mathrm{abc}$ & $1.6 \pm 1.2 \mathrm{~b}$ \\
Summer 2014 & $25.9 \pm 6.6 \mathrm{abcd}$ & $18.7 \pm 5.7 \mathrm{a}$ & $33.6 \pm 27.9 \mathrm{ab}$ \\
Autumn 2014 & $6.5 \pm 3.1 \mathrm{~cd}$ & $1.0 \pm 1.3 \mathrm{bc}$ & $9.1 \pm 5.2 \mathrm{~b}$ \\
Winter 2014 & $1.9 \pm 0.7 \mathrm{~d}$ & $18.6 \pm 8.0 \mathrm{ab}$ & $1.7 \pm 1.7 \mathrm{~b}$ \\
Spring 2014 & $75.2 \pm 27.5 \mathrm{a}$ & $28.1 \pm 15.3 \mathrm{a}$ & $8.7 \pm 5.1 \mathrm{~b}$ \\
Summer 2015 & $63.7 \pm 29.0 \mathrm{ab}$ & $12.7 \pm 5.1 \mathrm{abc}$ & $54.5 \pm 20.3 \mathrm{a}$ \\
Autumn 2015 & $30.1 \pm 15.2 \mathrm{abcd}$ & - & - \\
Winter 2015 & $11.6 \pm 1.5 \mathrm{bcd}$ &
\end{tabular}

*Means followed by a different letter in the column differ from each other according to the Duncan test $(\mathrm{P}<0.05)$.

Table 6. Average number of Diptera pupae (NP), number of Diptera adults (NA), and number of parasitoids (NPt) in the SPS and CPS.

\begin{tabular}{|c|c|c|c|}
\hline \multirow{2}{*}{ System } & \multicolumn{3}{|c|}{ Variables } \\
\hline & $\mathrm{NP}^{\mathrm{ns}}$ & $\mathrm{NA}^{\mathrm{ns}}$ & $\mathrm{NPt}^{*}$ \\
\hline SPS & $28.7 \pm 6.6$ & $11.5 \pm 2.3$ & $22.8 \pm 9.1 \mathrm{a}$ \\
\hline CPS & $35.1 \pm 10.1$ & $13.0 \pm 4.5$ & $6.3 \pm 2.0 \mathrm{~b}$ \\
\hline
\end{tabular}

\footnotetext{
${ }^{n s}$ not significant $(\mathrm{p}>0.05)$. ${ }^{*}$ significant by the Student-Newman-Keuls test $(\mathrm{p}<0.05)$.
} 
The trees in the silvopastoral system contributed to the maintenance of a favorable microclimate and an adequate environment for the invertebrate macrofauna living in cattle dung patches. The lower solar radiation, lower wind speed, and lower soil and air temperatures, associated with the greater abundance of floral resources and vegetal remains from the trees, allowed a better environment for shelter, feeding, and reproduction of the invertebrate macrofauna.

Tree species with a short foliar life span (deciduous trees) has a higher level of nitrate, chlorophyll and total nitrogen, than trees with long foliar life span, perennial trees (Lima et al., 2006). The floristic composition of SPS was composed of three deciduous tree species and four semi-deciduous tree species. The contribution of organic matter and the cycling of nutrients from the trees probably have favored the increase of microorganisms (fungi and bacteria) and the richness of edaphic macrofauna. Vallejo et al. (2012) indicated that the SPS is feasible and more sustainable alternative for improving soil quality and microbial metabolic compared to CPS, providing an important source of ecosystem services (nutrient cycling and soil physical structure maintenance).

The higher diversity and relative abundance of invertebrates, mainly carnivore (predators and parasitoids) insects, were registered in SPS. According to Brito et al. (2005), the majority of arthropods that control horn flies belong to the orders Hymenoptera (such as the parasitoids Spalangia migroaema and Spalangia cameronie and the ant Solenopsis invicta), Diptera (such as those of the family Muscidae) and Coleoptera (like Histeridae, Hidrofilidae, and Staphylinidae). In this study, we identified the following species of fly pupal parasitoids: Aphaereta sp. (Braconidae) and Spalangia sp. (Pteromalidae).

Soca et al. (2002) reported more significant degradation of dung patches in a silvopastoral system compared to open pasture ( $94 \%$ vs. $40 \%$ ), associating these data with the greater richness of edaphic fauna, especially coprophagous beetles (Scarabaeidae), which destroy and bury the fecal material, exposing the eggs and larvae of ectoparasites to other predators and increasing its risks of desiccation. Although we did not evaluate dung patches degradation in this study, our data about Scarabaeidae beetles were dissimilar to the Soca et al. (2002). Three morph-species of Scarabaeidae were registered, which relative abundance in CPS (0.0067) was higher than in the SPS system (0.0046).

Concerning the biological control of Dermatobia hominis and its phoretic species, Borja (2004) described that Sarcopromus capruna (Muscidae), Stomoxys calcitrans (Muscidae), Musca domestica (Muscidae), Haematobia irritans (Muscidae) and Fannia pusio (Fanniidae) are considered the most important phoretic insects that transport D. hominis eggs. In this experiment, we detected individuals of two morphspecies of Sarcophagidae and one of the Fanniidae in the dung patches of the cattle raised on both systems. Also, the ant species Solenopsis germinata, S. invicta, Steatoma quadridense, and Pheidole fallax were observed feeding on horn fly larvae and pre-pupae (Borja, 2004). As well, the mite Macrocheles muscae domesticae was observed on D. hominis pupae and adults (Borja, 2004). In our study, among the hymenopterous predators associated with the dung patches, Solenopsis sp. had densities in the spring, summer, and autumn of 125,34 , and 156 insects/15 dung patches, respectively, in the SPS, while the occurrence of this species was not observed in the CPS. Besides Solenopsis sp., two mite morph-species and one flower bug morph-species (Anthocoridae) occurred with significantly higher population density in the SPS, although it was not possible to be sure of their role as predators.

Once predators are generalists, they colonize the cattle feces and feed on the free forms of cattle ectoparasites (mainly larvae of $H$. irritans) present in the cattle feces. Previously reported data of research conducted in this area have demonstrated that densities of $H$. irritans were lower in cattle maintained on SPS, compared to CPS (Oliveira et al., 2017).

The higher densities of pupae parasitoids verified in the autumn, where the climatic conditions are characterized by low humidity and low temperature in this region, are corroborated with the data of Sulaiman et al. (1991). Studying the population patterns of the parasitoid Spalangia endius at a dumping ground near Kuala Lumpur city, they verified that the percentage of $S$. endius adult emergence varied seasonally. During the relatively heavy rainfall months, the population of $S$. endius adult emergence was low $(0-14.2 \%)$ compared to the less rainy months (emergence of $29.3-39.6 \%$ ). Low temperatures were related to higher densities of Nasonia vitripennis (Hymenoptera: Pteromalidae) parasitizing fly pupae in facilities during cold winter months when temperatures in the first-floor manure pits ranged from 12 to 16 degrees (Rutz and Scoles, 1989).

Nectar and pollen represent, in many cases, the main sources of nutrients required by the adult parasitoids (Meirelles et al., 2009), as well as excreta from some hemipterous insect (honeydew) (Wäckers et al., 2008). The forestry species in the SPS showed abundant flowering and probably served as a food resource for the adult of Hymenoptera parasitoids species, Aphaereta sp. and Spalangia sp., which were more prevalent in these systems, parasitizing fly pupae. According to Marchiori et al. (2003), Aphaereta sp. has gregarious behavior, and polyembryony is considered very ordinary, with several individuals emerging from the same pupae. Watts and 
Combs (1977) pointed out Aphaereta sp. as an important component in cattle excrements attacking pupae of $H$. irritans in the Mississippi estate (USA). Mendes and Linhares (1999) studying the occurrence and prevalence of parasitism by micro Hymenoptera of the horn fly, in south-eastern Brazil, verified that Spalangia nigroaenea and S. cameroni were the two most common parasitoids, suggesting that these species could be candidates for use in biological control. Borja (2004) observed the micro-hymenopterous parasitoids Trichopria (Ashmeadropia) mendesi, Spalangia nigroaenea, and Tachinaephagus zealandicus parasitizing D. hominis pupae. Auad et al. (2012) verified that the most of the Hymenoptera sampled in silvopastoral systems were beneficial agents, with a predominance of representatives from the family Formicidae, and entomophagous insects (Ichneumonidae and Braconidae) provide them with high levels of abundance, diversity, and constancy.

The higher structural complexity of the SPS favors biodiversity, which, as a rule, is a fundamental feature reducing parasites (Civitello et al., 2015). This complexity can explain our finding of the greater diversity of predators and Hymenoptera parasitoids associated with the dung patches in the SPS, and the lower ectoparasites densities verified by Oliveira et al. (2017) on cattle reared in this system.

\section{Conclusions}

The presence of trees in pastures alters the environment, notably through the reduction of solar radiation, decrease in wind speeds, attenuation of air and soil temperature, and diversification of food supply promoting insect richness in dung patches of cattle.

\section{Acknowledgments}

Thanks to Dra. Angélica Maria Penteado Martins Dias for the identification of the pupae parasitoids. This project was supported by São Paulo Research Foundation (FAPESP/2012-05858-0), Brazilian Agricultural Research Corporation (EMBRAPA/CPPSE, SEG 03.13.00.019.00.00) and Brazilian National Council for Scientific and Technological Development (INCT HYMPAR).

\section{Bibliographic References}

Amézquita, M.C., Ibrahim, M., Llanderal, T., Buurman, P., Amézquita, E., 2004. Carbon Sequestration in Pastures, SilvoPastoral Systems and Forests in Four Regions of the Latin American Tropics. Journal of Sustainable Forestry, 21(1), 3149.
Auad, A.M., Resende, T.T., Silva, D.M., Fonseca, M.G., 2012. Hymenoptera (Insecta: Hymenoptera) associated with silvopastoral systems. Agroforestry Systems, 85(1), 113-119.

Borja, G.E.M., 2004. Controle biológico do berne, Dermatobia hominis e de seus foréticos: crise e perspectiva. Revista Brasileira de Parasitologia Veterinária, 13(1), 111113.

Brito, L.G., Borja, G.E.M., Oliveira, M.C.S., Silva Netto, F.G., 2005. Mosca-dos-chifres: aspectos bio-ecológicos, importância econômica, interações parasito-hospedeiro e controle. Embrapa Rondônia (Comunicado Técnico, 302).

Burgess, P.J., 1999. Effects of agroforestry on farm biodiversity in the UK. Scottish Forestry, 53(1), 24-27.

Cardona, C.A.C., Ramírez, J.F.N., Morales, A.M.T., Restrepo, E.M., Orozco, J.D.C., Vera, J.K., Sánchez, F.J.S., Estrada, M.X.F., Sánchez, B.S., Rosales, R.B., 2014. Contribution of intensive silvopastoral systems to animal performance and to adaptation and mitigation of climate change. Revista Colombiana de Ciencias Pecuarias, 27(2), 76-94.

Civitello, D.J., Cohen, J., Fatima, H., Neal T., Halstead, N.T., Liriano, J., McMahon, T.A., Ortega, C.N., Sauer, E.L., Sehgal, T., Young, S., Rohr, J.R., 2015. Biodiversity inhibits parasites: Broad evidence for the dilution effect. Proceedings of the National Academy of Sciences, 112(28), 8667-8671.

Di Rienzo, J.A., Casanoves, F., Balzarini, M.G., Balzarini, M., Gonzalez, L., Tablada, M., Robledo, C.W., 2011. InfoStat Software estadístico. http://www.infostat.com.ar (acessado 04 de fevereiro de 2019).

Euclides, V.P.B., Euclides Filho, K., 1998. Uso de animais na avaliação de forrageiras (EMBRAPA-CNPGC. Documentos, 74).

Ferrari, A.C., Soares, A.T.C., Amorim, D.S., Thyssen, P.J., Guimarães, M.A., 2009. Comparação dos padrões de atratividade de Hermetia illucens (Diptera,Stratiomyidae) associada a carcaças de Rattus norvergicus enterradas e tratadas com hormônios esteroides. Revista Brasileira de Entomologia, 53(4), 565-569.

Gorgen, C.A., Civardi, E., Perreto, E., Carneiro, L.C., Silveira Neto, A.N., Ragagnin, V., Lobo Junior, M., 2008. Controle de Sclerotinia sclerotiorum com o manejo de Brachiaria ruziziensis e aplicação de Trichoderma harzianum. Embrapa Arroz e Feijão (Circular Técnica, 81).

Grisi, L., Leite, R.C., Martins, J.R.D.S., Barros, A.T.M., Andreotti, R., Cançado, P.H.D., León, A.A.P., Pereira, J.B., Villela, H.S., 2014. Reassessment of the potential economic impact of cattle parasites in Brazil. Revista Brasileira de Parasitologia Veterinária, 23(2), 150-156.

Inomoto, M.M., Machado, A.C.Z., Antedomenico, S.R., 2007. Reação de Brachiaria spp. e Panicum maximum a Pratylenchus brachyurus. Fitopatologia Brasileira, 32(4), 341344.

Jose, S., 2009. Agroforestry for ecosystem services and environmental benefits: an overview. Agroforestry Systems, 76(1), 1-10. 
Kaimowitz, D., Angelsen, A., 2008. Will livestock intensification help save Latin America's tropical forest? Journal of Sustainable Forestry, 27(1), 6-24.

Lima, A.L.S., Zanella, F., Schiavinato, M.A., Haddad, C.R.B., 2006. Nitrogenous compounds, phenolic compounds and morphological aspects of leaves: comparison of deciduous and semideciduous arboreal legumes. Scientia Agricola, 63(1), 4045 .

Marchiori, C.H., Pereira, L.A., Filho, O.M.S., 2003. Aphaereta sp. (Hymenoptera: Braconidae: Alysiinae) as a natural enemy to Peckia chrysostoma (Wiedemann) (Diptera: Sarcophagidae), in Brazil. Brazilian Journal of Biology, 63(1), 169-172.

Meirelles, A.P., Carneiro, T.R., Fernandes, O.A., 2009. Efeito de diferentes fontes de carboidrato e da privação de alimento sobre aspectos biológicos de Telenomus remus Nixon (Hymenoptera, Scelionidae). Revista Brasileira de Entomologia, 53(3), 457-460.

Mendes, J., Linhares, A.X., 1999. Diapause, pupation sites and parasitism of the horn fly, Haematobia irritans, in southeastern Brazil. Medical and Veterinary Entomology, 13(2), 185-190.

Mendes, J., Linhares, A.X., 2002. Cattle Dung Breeding Diptera in Pastures in Southeastern Brazil: Diversity, Abundance and Seasonallity. Memórias do Instituto Oswaldo Cruz, 97(1), 37-41.

Navas, A., Ibrahim, M., Alvarez, V., Casanoves, S., Mora, J.R., 2008. Influence of silvopastoral systems on the distribution of ticks in livestock farms in tropical dry forest. Revista Colombiana de Ciência Animal, 1(1), 38-40.

Odum, E.P., 1983. Ecologia, terceira ed. Guanabara, Rio de Janeiro.

Oliveira, M.C.S., Nicodemo, M.L.F., Gusmão, M.R., Pezzopane, J.R.M., Bilhassi, T.B., Santana, C.H., Gonçalves, T.C., Rabelo, M.D., Giglioti, R., 2017. Differential Haematobia irritans infestation levels in beef cattle raised in silvopastoral and conventional pasture systems. Veterinary Parasitology, 246(1), 96-99.

Pezzopane, J.R.M., Bosi, C., Nicodemo, M.L.F., Santos, P.M., Cruz, P.G., Parmejiani, R.S., 2015. Microclimate and soil moisture in a silvopastoral system in southeastern Brazil. Bragantia, 74(1), 110-119.
Pielou, E.C., 1975. Ecological Diversity. John Wiley and Sons, New York.

Rutz, D.A., Scoles, G.A., 1989. Occurrence and Seasonal Abundance of Parasitoids Attacking Muscoid Flies (Diptera: Muscidae) in Caged-Layer Poultry Facilities in New York. Environmental Entomology, 18(1), 51-55.

SAS Statistical Package, 2003. System for Microsoft Windows, Release 9.1, SAS - CD Room, Cary, NC, USA.

Soca, M., Simón, L., Sánchez, S., Gómez, E., 2002. Dinámica parasitológica en bostas de bovinos bajo condiciones silvopastoriles. Agroforestería en las Américas, 9(33-34), 3842.

Soil Survey Staff, 2014. Keys to Soil Taxonomy, twelfth ed. Washington, DC: USDA-Natural Resources Conservation Service, Washington, DC.

Sulaiman, S., Omar, B., Omar, S., Jeffery, J., Ghauth, I., Busparani, V., 1991. Seasonal Population Patterns of Spalangia endius Walker (Hymenoptera: Chalcidoidea) at a Refuse Dumping Ground in Malaysia. Journal of Medical Entomology, 28(6), 757-759.

Thornthwaite, C.W., Mather, J.R., 1955. The water balance. Drexel Institute of Technology, Centerton.

Tobin, P.C., Pitts, C.W., 1999. Flotation method for extracting insects from poultry manure samples. Journal of Medical Entomology, 36(1), 121-123.

Vallejo, V.E., Arbeli, Z., Terán, W., Lorenz, N., Dick, R.P., Roldan, F., 2012. Effect of land management and Prosopis juliflora (Sw.) DC trees on soil microbial community and enzymatic activities in intensive silvopastoral systems of Colombia. Agriculture Ecosystems \& Environment, 150(1), 139-148.

Wäckers, F.L., Van Rijn, P.C.J., Heimpel, G.E., 2008. Honeydew as a food source for natural enemies: Making the best of a bad meal? Biological Control, 45(2), 176-184.

Watts, K.J., Combs Jr., R.L., 1977. Parasites of Haematobia irritans and Other Flies Breeding in Bovine Feces in Northeast Mississippi. Environmental Entomology, 6(6), 823-826. 